\title{
ELECTIONS AND DEMOCRATIC DEFICITS IN NIGERIA'S FOURTH REPUBLIC: A COMMENTARY
}

\author{
Al-Chukwuma Okoli ${ }^{1}$ \\ Chigozie Joseph Nebeife ${ }^{2}$ \\ Markus Arum Izang ${ }^{3}$
}

\section{Introduction}

The modern world's appreciation of peoples' participation in the determination of who governs the affairs of the state in the overall interests is observably the underpinning factor for the global celebration of democracy as a system of government (Igbokwe-Ibeto, Osakede, Nkomah \& Kinge 20I6). Cardinal to all democracies is public participation, at least at the leadership selection level by the instrumentality of election. This is, essentially, because democracy is a government designed to serve the interests of the public. Political scientists associate elections with democratic governance by arguing that election is the machinery that provides the avenue for the emergence of a constituted government. Also, elections have become an acceptable mode of legitimate political succession.

Separating election from democracy is nearly impossible due to their organic functional relationship. Extant scholarship recognizes this nexus by affirming that it is through elections that formal transfer of power occurs in all democracies. Besides, it is also through the medium of election that legitimacy is conferred on a government. Election depicts the social contract between representatives and the represented. This is to the effect that the electorate reserves the right to vote in or vote out a government at any instance of election (David, Manu \& Musa 20I4).

I Department of Political Science, Federal University Lafia. Lafia, Nigeria. E-mail: okochuoo7@yahoo.com

2 Department of Political Science, Federal University Lafia. Lafia, Nigeria. E-mail: arummarkus@gmail.com

3 Department of Political Science, Federal University Wukari. Wukari, Nigeria. E-mail: cjnebeife@gmail.com 
In effect, election has remained indispensable to the practice of democracy. It also constitutes a yardstick for determining and measuring democratic consolidation and progress (Powell 2000; Berouk 2008). Incidentally, while election is universally acclaimed as the quintessence of democracy, Nigeria's experience with election has been rather disheartening. In fact, elections in Nigeria have passed for a veritable de-democratizing factor in her democratic experience. First, rather than providing an avenue for smooth and legitimate transfer of power, elections have been associated with untoward occurrences that have often vitiated the prospect of a seamless transition. Second, instead of bridging the gap between the electorate and their elected representatives, elections in Nigeria have largely lost its essential democratic essence and ingredients: (i) they are often compromised to the extent that the outcome does not reflect the will or wishes of the electorate (ii) even when they are credible, the elected representatives do not feel that they hold their mandate at the instance of the electorate; (iii) there is hardly any meaningful synergy between the electorate and their representatives in the aftermath of the election; (iv) elected representatives conduct themselves in government with little or no regards to the yearnings and aspirations of the electoral populace.

It is in the light of this that this study examines elections and democratic deficit in Nigeria's Fourth Republic. The essence is to interrogate the seemingly ironic reversals of democratic tenets in the processes of politics and governance, even as the country democratizes. The paper contends that Nigeria's experience with democracy has largely amounted to nominal civilianizing, in view of the fact that what is on course has not fulfilled minimal requirements of the democratic order.

\section{Conceptualizing democracy, democratic deficit, election}

The term democracy is derived from the Greek word "democratia", basically designating "a political arrangement in which political power is vested in the majority of the citizen" (Adejumobi 2004, 5). It is a form of government in which people willingly and freely choose their leaders through free and fair direct or indirect election process (Osabiya 20I4). In this system of government, the people enjoy the fundamental freedoms of speech, association, assembly, conscience etc. In it also are such institutions as an independent judiciary, free press, competitive party system and an active civil society. 
Democracy could be used to describe a government that is based on the ideas of majoritarian rule and popular representation of the true interests of the public. It has its essence in a free and open society, where individuals are free to develop themselves and where those in power are kept in check by a combination of civil institutions and procedures. Some of the fundamental attributes of democracy include the rule of law, periodic election, and civic political culture. A popular expectation is that democracy is a prerequisite for good governance: it should provide the material conditions for the improvement of society in terms of literacy, security of life and property, better health, employment, food security, potable water and rural development, as well as ensure political stability. The inability of a democratic system to guarantee the above is herewith conceived as democratic deficit.

To be sure, democratic deficit has to do with the inadequacies of the democratic practice comparative to the ideals of democracy. Deficit means a shortage or a lack of/in something. Lack of democratic institutions in terms of existence and poor capacity for the existing ones to optimally discharge legitimate responsibilities translate into failures and hinder democratic efficiency. Democratic deficit implies that the values of democracy are lacking in a democratic society (Dahl I999). Democratic deficit entails the disparities between the perceived democratic performance and public aspirations (Russell 2004). Roller (2005) states that democratic deficit can be the consequence of a regime whose rules, procedures, and institutions are unable to provide what citizens look for and aspire to.

Also, Norris (20II) notes that democratic deficit depicts a situation where the electoral system fails to satisfactorily channel the preferences of the voters. It has to do with instances where democratic institutions are falling short of the principles of responsiveness and accountability in their operations. It is this lack of responsiveness to the popular preferences and democratic oversight that is known as the democratic deficit (Dahl I999). Democratic deficit may be linked to democratic illegitimacy or irresponsibility occasioned by distorted flow of influence from citizens to government through popular mandate mediated by periodic elections.

The concept of election refers to the process through which qualified citizens are allowed to participate in determining who pilots the affairs of a particular state or organization either by voting or standing as candidates. It is a process that begins from political campaign and ends at the emergence of an individual or group to represent the public in government. Ibeanu (2007) states that election entails the process by which citizens choose preferred candidates to run their government at all levels in an episodic framework 
for a specific tenure of office. It entails the process of selecting the people who would be saddled with the responsibility of determining who gets what, when and how in a polity through balloting, which entails making choice between alternatives (Lasswell I936). This is to say, therefore, that election is a formal group decision making process by which a population chooses an individual or group to hold public office in their collective interests. Election is a major ingredient of modern democracies in the world.

\section{Theoretical premise: from elite control to elite capture}

This study derives it theoretical anchor from the elite capture theory. The earlier versions of the theory emphasized personal attributes of leaders, which aided their hold or dominance in power positions while the new versions dwelt more on the institutional framework of society. The political elites are usually located within the mainstream power structures of any nation-state and are responsible for managing the political and administrative affairs (Platteau 2004). The elite capture theory is anchored on the assumption that most societies are dominated by elites that are free from popular control and pursue their peculiar interest defined in terms of power and self-aggrandizement. It entails a situation where a fraction of the society has the power to take decisions which affect society and these decisions usually reflect the interest of the elites rather than the wishes of the majority. General elite theory argues that the elite possess some qualities necessary for their accession to political power, such as consciousness, coherence, conspiracy and organisation. Members of the elite are thus not only aware of their status, but work determinedly to protect it with the use of exclusionary factors in leadership.

Platteau (2004) notes that elites perpetuate their dominance through land holding practices, family networks, employment status, wealth, political and religious affiliation, as well as personal history and personality. This suggests that what makes elite capture so powerful and dominant is that elites exert their influence less often by coercion, and more by moral claims and symbolic power (Dasgupta and Beard 2007). The dynamics of elite domination and manipulation is sustained and reproduced via the process of elite circulation. This mechanism ensures elite continuity, transformation and replacement through which elites cooperate, compete and reconcile their differences from time to time (Higley \& Burton 2006).

The elites in Nigeria's Fourth Republic tend to have kept virtually all the state apparatus at hostage through skewed electoral process and undemocratic governance. Democratic institutions in Nigeria such as the legislature, 
executive, judiciary, and regulatory agencies have been captured by the elites thereby weakening the capacity of the state to ensure rule of law. This has resulted to lack of accountability, unprecedented abuse of power for selfish pursuit and personal aggrandizement, as well as crass misrule. The elites focus on control of political and state power for protecting and promoting the interests of members at the expense of the masses. The consequence is antithetical to democracy for it negates the salient attributes thereof, such as accountability, responsiveness and transparency. This is a threat to democratic consolidation in Nigeria.

\section{Election and democratic representation/consolidation in Nigeria: an overview}

Election depicts a social contract between representatives and the represented and also provides opportunity for transition from particular sets of representatives and office holders to another (David, Manu \& Musa 20I4). Ayoade (2006) describes election as the process of actualizing representative democracy. It is a method of selecting a few people from a large group such that the few people become a representative of the large group. Nnadozie (2004) posits that election is a medium through which individuals or groups are chosen in order to represent their constituencies in the context of governance.

Scholars such as Schumpeter (I942), Linz and Stepan (I996), Przeworski (1997) and Omotola (2014) have separately noted that elections are the first and most basic indicator of democracy because of their presumed capacity to guarantee political participation, competition and legitimacy which, in turn, are pivotal to democratic consolidation. This implies that competitive elections provide a framework quintessential to organizing democratic uncertainty in order to produce legitimate change, rebirth, renewal and power alternation (Przeworski I997).

Since the democratic transition heralding the Fourth Republic in Nigeria in I999, Elections have been aggressively contested. This is owing to its strategic place a means to gaining access to the control of state power which is considered to be the prime source and/or sustainer of material wealth and livelihood security (Fadakinte 2013). This thinking has, over the years, informed a pattern of politicking that involves desperate competition for power, making pursuit of state power a matter of 'a do or die affair' where the winner takes all and the loser loses all. 
This situation is complicated by the character of Nigeria's political class which is not in tune with the ideology of liberal democracy. To be sure, the dominant political class does not possess the requisite democratic ethos, such as tolerance, discipline and democratic temper to engage in credible elections (Fadakinte 20I3). Due to the desperate desire by politicians to win elections at all costs in order to enjoy the perquisites of power, elections in Nigeria have often been characterised by violent confrontations, bringing about outcomes that negate democratic consolidation and sustainability. In the process, the country at every turn of election becomes crisis ridden and prone to instability.

The crisis of electoral democracy in Nigeria is endemic. Over the years, it has manifested in the forms of excessive manipulation, monetization and structural emasculation of the electoral processes, with widespread irregularities and violence (Ademola \& Adenuga 20I5). This tendency has persisted across all elections in the Fourth Republic and has taken the form of widespread illegitimate use of state power (abusive incumbency advantage) as well as money (vote-buying/selling) to influence a preferred outcome in an election. This has found expression in heavy monetization and militarization of the electoral process whereby the electioneering experience assumes the complexion of a 'market' as well as a 'war' scenario.

Furthermore, election in Nigeria appears to have been characterised with poor administration, often defined by a seemingly weak and inefficient electoral umpire. The Nigerian 1999 Constitution as amended and the 2010 Electoral Act as amended has empowered Independent National Electoral Commission (INEC) as the electoral umpire to organize and conduct elections into various political offices in the country. However, each elections conducted by INEC have always been flawed by INEC's poor organization, lack of accountability and transparency (Edet 20I5). The weakness of election-mediating institutions such as Police, INEC, the courts etc. has effectively reduced Nigeria's elections to mere periodic rituals, yielding little or no meaningful democratic outcomes. This affirms the position of Dudley (1982) to the effect that Nigeria parades weakly institutionalized political institutions which are incapable of handling pressures from the political system. Hence, successive elections in Nigeria have been generally poor as the electoral umpire (INEC) seems to have been heavily influenced and manacled by the vested interests of the powers that be (the forces of incumbency). This has vitiated the prospect of delivering on the task of conducting free, fair and credible elections in Nigeria.

By the above indices, election in Nigeria can be said to have amounted to a contradiction of the traditional theoretical postulations that election is the fulcrum of democracy which carries a premium of political representation as well as legitimizing a government through popular mandate. This gross 
negation of the cardinal democratic principles in relation to electioneering in Nigeria holds critical implications for the country's democratic representation and consolidation. Thus, achieving the essence of democratic representation and consolidation seem to have remained utopian. As observed by Nwanegbo (20I5), that the manipulative nature of electioneering instantiated by massive riggings, diabolic politicking, violent electioneering, vote selling/buying among many irregularities, explain why elections seem not have resulted to true democratic representation and consequent consolidation in Nigeria.

Elections in a democracy are not a simple transfer of decision-making powers onto the political representatives. This is because a mere possession of political autonomy and subjectivity by a voter does not always determine his or her credible participation in the elections. By this token, Democratic representation entails peoples' government or popular rule. Popular rule entails a governmental process of defining, collecting, harmonizing, promoting and protecting the general interests of the people for the betterment of life in the entire society. Here, it is the general concern and responsibility of all to manage the affairs of their society to bring about improvement in the quality of life by increased general access to the basic needs of life. But since people cannot do this all together at once, they do it through a freely 'democratically' elected few called the representatives. Democratic representation can be regarded as a system of government that is underpinned by the perception that people in any society should be free to determine their own political, economic, social, and cultural systems. Therefore, democratic representation simply refers to a political system where governance is rooted in the basic principles of democracy and carried out by individuals who are willingly and freely chosen by the people.

The system of government in a democracy is one under which the people exercise the governing power either directly or through representatives periodically elected by them (Appadorai 2004). Thus, representation is widely seen as the pillar of contemporary democratic leadership. The implication is that the only government which can fully satisfy all the exigencies of collective civic life is one in which majority of the citizens take active part. However, direct inclusive participation is only achievable in a small populated community and not in a highly populated and complex modern society, hence, the necessity for representation in government. Simply put therefore, representation implies the indirect presence of people in the management of their public or state affairs.

The above corroborates the assertion of Fairlie (I940), that democratic representation depicts that system of government where the powers are delegated to elected representatives, who exercise them for the benefit of the whole nation. Suggestively, democratic representation is the activity of making 
citizens' voices, opinions and perspectives 'present' in public policy making processes. It occurs when political actors speak, advocate, symbolize and act on behalf of their electorates in the political arena. Laying the philosophical foundation of representative governments, renowned political philosophers and theorists as Hobbes in his Leviathan, Plato in The Republic and Machiavelli in The Prince, observably advanced that public decision making should be left as a responsibility of a few members of the community.

According to Lincoln's famous perspective that democracy is government of the people, by the people and for the people, democratic regime provides a platform for selected individuals to represent their people because it is only by courtesy of such an arrangement that government can hope to attain the status of people's rule. It is to be observed that the essence of democratic representation is to enable the people have not only a say in the management of their society, but that they can also control effectively how the state is run and what policy is implemented for their general good. Incidentally, there are indications that electorates have not been able to determine the quality of their lives as well as the fate of their state through democratic representation in the Nigeria's Fourth Republic.

The idea of democratic consolidation means an identifiable phase in the process of transition from authoritarian to democratic systems that are critical to the establishment of a stable, institutional and lasting democracy. Democratic consolidation entails strengthening, entrenching and institutionalizing democratic ideals, values and virtues in a political system. It has to do with the avoidance of authoritarian regression; particularly, through the institutionalization of a credible electoral administration process. This is in tune with the assertion Linz and Stepan (I996, ro) that "democracy is consolidated when under given political and economic conditions, a democratic system expressed in periodic and regular elections becomes the only game in town; when no one can imagine acting outside the democratic norms and values". Democratic consolidation, therefore, involves strengthening of certain institutions, such as the electoral system, revitalized or newly created parties, judicial independence and respect for human rights, which have been created or recreated during the course of the transition (Carothers 2007). Thus, Democratic consolidation revolves around making new democracies secure and extending their life expectancy beyond the short term by creating immune against the threat of authoritarian regression and building dams against eventual reverse to authoritarianism (Carothers 2007; Fawole 2005; Przeworski I997; Zakaria 1997). The implication of this is that election serves as a critical framework for democratic consolidation with ultimate regard for the rule of law (Frempog 2006; Sha 2005). 
According to Diamond (I999) creating a stable, democratic, effectively governed politics is an enormous challenge for any developing country that has experienced predominantly political instability, democratic failures and institutional decay since independence. It implies series of continuous actions and changes geared toward the replacement of an existing system of authoritarian and undemocratic rule (Yagboyaju 2007). Some other scholars view democratic consolidation as the process by which a new democracy matures in a way that means it is unlikely to revert to authoritarianism without an external shock or a process of democratization that resist the tendencies of reversing or regressing back to the dark days of authoritarian military regime (Linz \& Stepan I996; Asiwaju 2000; Mortiar 2002; Jega 2007; Yagboyaju 2007). More specifically, democratic consolidation, "implies the internalization of democratic culture and the institutionalization of democratic best process" by a polity that has successfully embarked on a democratic transition (Asiwaju 2000, 4). Thus, consolidating democracy means reducing the probability of breaking to a point where they can feel reasonably confident that democracy will persist in the near future (Schedler, in Egbegbulem 20II). Thus, Schedler as cited in Egbegbulem (2011, 67) contends that:

[...] consolidating democracy may involve the positive tasks of deepening a fully liberal democracy or completing a semi democracy or it may respond to the "negative" challenges of impeding the erosion of a liberal democracy or else avoiding the breakdown of whatever minimal kind of democracy we have in place [...] (Egbegbulem, 20II, 67).

Linz and Stepan (I996) posit that the key indicators of democratic consolidation include credible elections, and the rule of law, free and active civil society, relatively autonomous and valued political society, functional bureaucracy as well as institutionalized economy. Democratic consolidation prevails in societies where many of the prominent democratic principles largely constitute positive political culture. According to Przeworski as cited in Mortiar (2002) democracy is consolidated when under given political and economic conditions a particular system of institutions become the only game in town. It is when no one can imagine acting outside the democratic institutions, when all losers want to do is to try again within the same institutions under which they lost (Mottier 2002).

In his view, Jega $(2007,297)$ argues that democratic consolidation is a term which describes "a vital political goal for new democracies". Diamond cited in Jega $(2006,6)$ stated that "Democratic consolidation has to with overlapping behavioural, attitudinal and constitutional dimensions, through 
which democracy becomes routinized and deeply internalized in social, institutional, and even in psychological life, as well as in political calculations for achieving success" (Jega 2007, 6). Linz and Stepan (I996) earlier provided further explanation on behavioral, attitudinal and constitutional aspects of democratic consolidation. They explained that behaviorally, a democracy is consolidated when no significant national, social, economic, political or institutional actors spend significant resources attempting to achieve their objectives by creating a non-democratic regime or by seceding from the state.

Democratic consolidation could also be viewed from the standpoint of stability of the democratic processes with emphasis on regular and credible elections (Igbuzor 2005; Akinsanya 2006). Thus, it is important to state that elections are the foundation for any successful democracy and indeed its consolidation. However, emphasis on elections as a stepping stone towards consolidating democracy seems to be questionable especially when taken into cognizance Nigeria's experience, mainly characterized so far by electoral malfeasance and structural infractions that detract from the merit of electoral democracy. And besides the question of electioneering, the outcome of the electoral processes in Nigeria's Fourth Republic has left much to be desired of the essence of the social contract between the electorate and their elected representatives which is serviced by way of routine elections. The question then is whether successive electoral dispensations in that context have engendered substantive outcomes that leverage democratic dividends. The following subsections attempt to proffer relevant insights in that regard.

\section{Contexts and indicators of democratic deficits in Nigeria's Fourth Republic}

Nigerian democracy is running on weak foundations (Adeniyi 20I8). This is because the enabling structures and culture required to effectuate and consolidate the practice are either nonexistent or inefficient. In effect, therefore, the practice has been characterized by both structural and functional deficits. For the purpose of our discourse in this paper, democratic deficits could be seen in three different dimensions: normative, empirical and functional perspective (Ogbonna 2012). From the normative perspective, democratic deficit occurs when political arrangements and institutions fail to satisfy public expectation and aspiration; this defies the expectation that popular political participation (mostly through election) makes government responsive to the needs and aspirations of the people. On the other hand, the empirical perspective sees democratic deficit in a government in terms of citizens ability or otherwise to utilise their civic stake in governance to make 
their government amenable to their wishes or interests. In the functional perspective, a government is democratically deficient when it is unable to generate appreciable popular legitimacy from the people. These three dimensions of democratic deficit have generally manifested in Nigeria's Fourth Republic.

The ruling elites and democratic institutions have failed to provide the enabling civil infrastructure for sustainable and profitable democratization. Instead, cycles of civilian governments have been characterised by false starts, failed transitions, and recurring challenges to stable rule. Elected regimes have faltered over precarious institutions, factionalism among elites and pervasive corruption (Peter, Alemika \& Michael 2002; Osaghae \& Larry I995). With reference to Nigeria's Fourth Republic, democratic deficits have been variously made manifest by virtue of the indicators considered hereunder.

\section{Alarming poverty rate}

The trajectory of Nigeria's poverty level from I999 has maintained an unfortunate increase. In 20I8, the World Poverty Clock ranked Nigeria topmost in terms of countries of the world with the largest concentration of people living under extreme poverty as captured below in Figure I:

Figure 1: Nigeria's poverty level, 2018

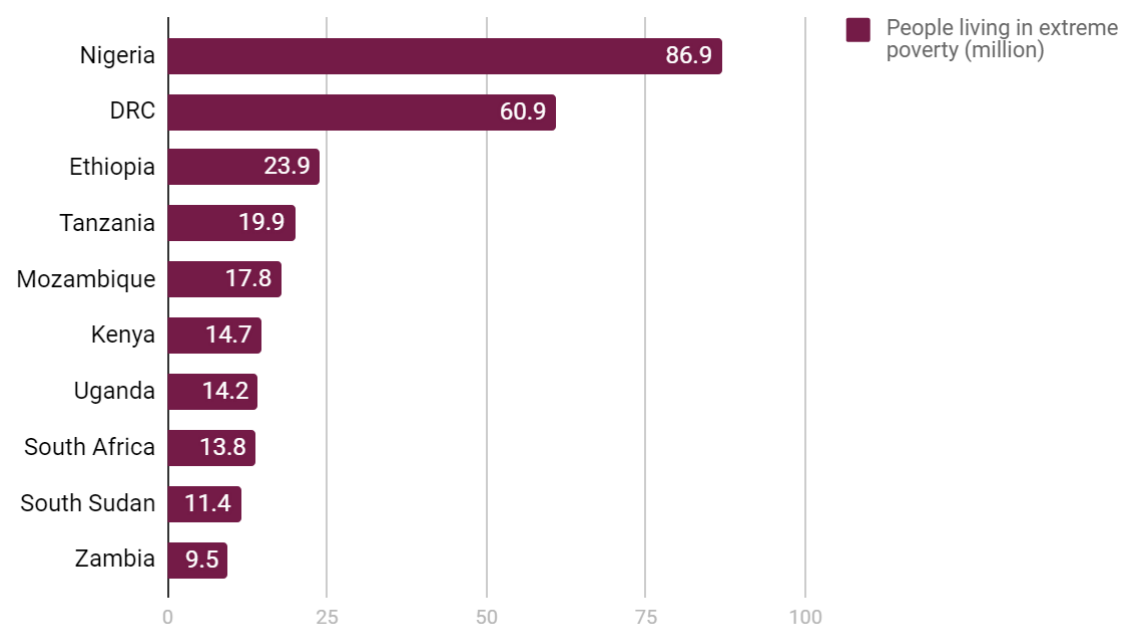

Source: Sahara Reporters, 20I9. https://qz-com.cdn.ampproject.org 
The above indicates that about 46.5 per cent of the country's population reportedly lives below poverty line of a dollar per day (Sahara Reporters 20I9). This is unfortunate when considered against the backdrop of the country's huge material and human endowments. It only explains the inability of the various democratic governments in the country over the years to improve the general living conditions by way of proper needs-based authoritative allocation of values/resources.

\section{Security debacle}

Burton (20I9) having empirically studied incidences of security threats across the globe, placed Nigeria as the fifth most threatened/dangerous country in the world in terms of safety and security indices. Table I is instructive in this regard.

Table 1: Most dangerous countries in the world

\begin{tabular}{|c|l|c|c|l|c|}
\hline Rank & \multicolumn{1}{|c|}{ Country } & $\begin{array}{c}\text { Ranking } \\
\mathbf{2 0 1 8}\end{array}$ & Rank & Country & $\begin{array}{c}\text { Ranking } \\
\mathbf{2 0 1 8}\end{array}$ \\
\hline 1 & Central African Republic & 149 & 11 & Cameroon & 139 \\
\hline 2 & D.R. Congo & 148 & 12 & Libya & 138 \\
\hline 3 & Iraq & 147 & 13 & Kenya & 137 \\
\hline 4 & Afghanistan & 146 & 14 & Burundi & 136 \\
\hline 5 & Nigeria & 145 & 15 & India & 135 \\
\hline 6 & Sudan & 144 & 16 & Ukraine & 134 \\
\hline 7 & Pakistan & 143 & 17 & Mexico & 133 \\
\hline 8 & Colombia & 142 & 18 & Uganda & 132 \\
\hline 9 & Philippines & 141 & 19 & Chad & 133 \\
\hline 10 & Yemen & 140 & 20 & Mali & 134 \\
\hline
\end{tabular}

Source: Burton (2019)

This is also a glaring indicator of democratic deficit in Nigeria's Fourth Republic. Ensuring the safety and security of the people is the essence of government generally, but more fundamentally in a democracy being 
people's government. However, the democratic institutions in control of the state's coercive apparatuses have by-and-large failed to secure maximally, human lives and resources and hence the prevalence of insecurity in the country. This is instantiated by the incidences of Boko Haram insurgency, armed banditry, militancy and a host of other security threats in the country.

\section{Infrastructural and industrial deficits}

Infrastructural deficits include collapse of basic amenities and public facilities in the country. This is amply exemplified in the near extinction of railways, as well as the colossal dilapidation of road networks, public schools, health and water facilities. Public power has been at its lowest ebb, with less than $5.000 \mathrm{MW}$ generation capacity alongside intractable distribution and transmission challenges. Allied to the problem of infrastructure is that of poor industrial base.

The Nigerian industrial sector is in virtual comatose. The Nigerian textile industry, steel rolling mill, rubber, woods, cement, fertilizer, ceramics and publishing industries were vibrant and internationally competitive in the I970 and I980s. Currently, there operational capacities are being dwarfed by high cost of production caused by epileptic power supply, high interest and exchange rates, influx of inferior and substandard products, multiplicity of taxes and levies, poor sales partly as a result of low purchasing power of the consumers, delay in clearing consignments due to existence of multiple inspection agencies at the ports etc. The national refineries are struggling to maintain nominal serviceability while the mega Ajaokuta iron and steel project has suffered a generational neglect.

\section{Heightened unemployment}

Nigeria's unemployment records are colossal (Figure 2). The situation holds critical implications for human security in Nigeria. An integral facet of Nigeria's unemployment palaver is the issue of youth unemployment and unemployability. More than a half of the unemployed population of Nigeria is youth, most of whom are educated at the tertiary level. 
Figure 2: Unemployment rate in Nigeria, 2016-2018

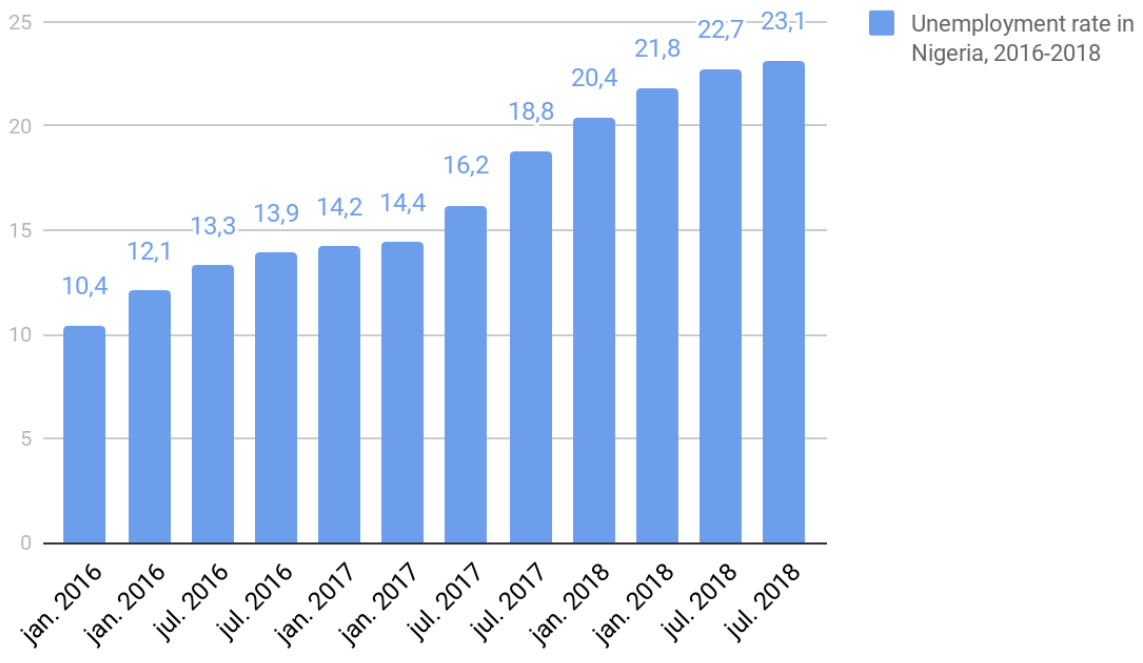

Source: Nigerian Bureau of Statistics, 2018

The non-engagement of the magnitude of the country's youth in gainful employment has led to dire collateral consequences, including youth bulge, youth restiveness, and associated vices and crimes. The prevalence of these existential situations in the country speaks ill of success of democratic governance in Nigeria.

\section{Brain-drain/Human capital depreciation}

There has been a persistent exodus of Nigerian best brain for better livelihood opportunities (Figure 3) outside the shores of the country. This brain-drain syndrome critically affects the country's human resource development index as Nigerian professionals in diverse fields especially health and education sectors daily exit the country for Europe, America and Canada among other developed countries in search of greener pasture. About 5,405 
Nigerian trained doctors and nurses currently work with the British National Health Service (NHS) in the United Kingdom. This has aggravated Nigeria's physician-patient ratio from I:4000 to I:5000, negating the W.H.O's recommended r:6oo. The irony of the situation is that Nigeria incidentally ranks so highly in terms of patronage of international medical and educational tourism.

Figure 3: Reasons for brain-drain in Nigeria

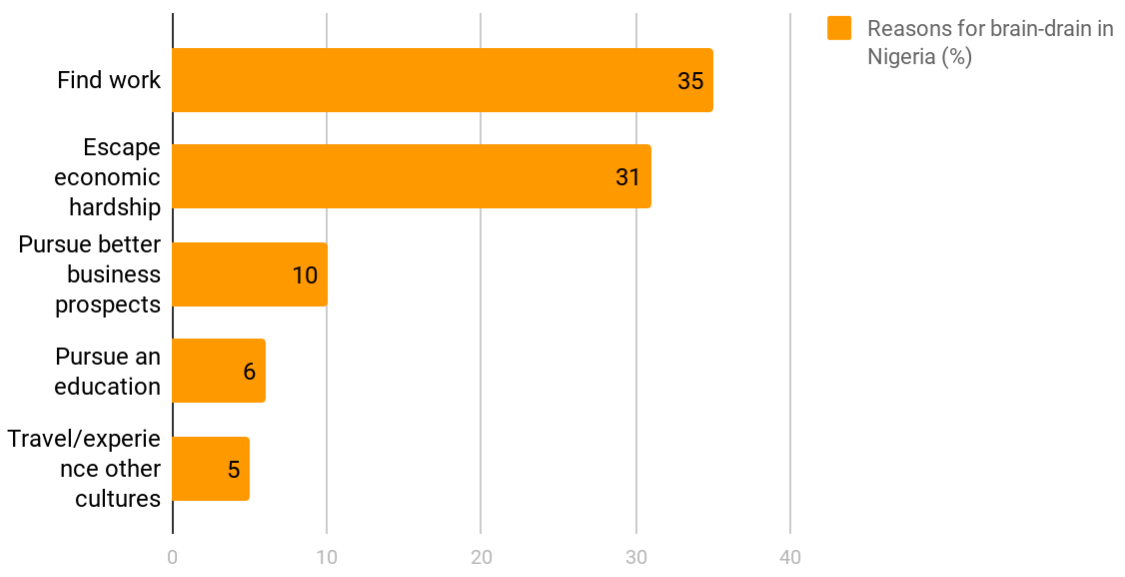

Source: https://www.timeslive.co.za/news/Africa/2018-09-05-a-third-of-nigerians-want-to-emigrate-but-not-to-south-africa

Allied to the issue of brain-drain is the crisis of the education sector. The sector has suffered enormous neglect, yielding therefore dysfunctional outcomes. This has pushed many Nigerians into the option of seeking to study abroad. Hence, the number of Nigerians schooling in universities in the West has been alarming (Table 2). 
Table 2: Number of Nigerian students in America, 2005-2016

\begin{tabular}{|l|c|c|c|c|c|}
\hline Year & Undergraduate & Graduate & OPT $^{4}$ & Other & Total \\
\hline $2015 / 16$ & 5,424 & 3,803 & 1,231 & 216 & 10,674 \\
\hline $2014 / 15$ & 4,770 & 3,339 & 1,198 & 187 & 9,494 \\
\hline $2013 / 14$ & 4,030 & 2,771 & 997 & 115 & 7,921 \\
\hline $2012 / 13$ & 3,707 & 2,551 & 953 & 105 & 7,316 \\
\hline $2011 / 12$ & 3,577 & 2,522 & 819 & 110 & 7,028 \\
\hline $2010 / 11$ & 3,772 & 2,454 & 799 & 123 & 7,148 \\
\hline $2009 / 10$ & 3,490 & 2,327 & 646 & 97 & 6,566 \\
\hline $2008 / 09$ & 3,513 & 2,153 & 516 & 74 & 6,256 \\
\hline $2007 / 08$ & 3,745 & 1,968 & 438 & 71 & 6,222 \\
\hline $2006 / 07$ & 3,569 & 1,820 & 483 & 71 & 5,943 \\
\hline $2005 / 06$ & 4,102 & 1,819 & N/A & 271 & 6,192 \\
\hline
\end{tabular}

Source: wenr.wes.org.google.com

\section{Corruption incidence and prevalence}

Corruption has remained a prominent issue in Nigeria's national question. Several rankings have placed the country among the topmost in terms of global corruption incidence especially within the Fourth Republic. Transparency International (Figure 4) indicates how corruption has persistently threatened to endanger the collective destiny of the nation from 2010 to 2018 .

4 Optional Practical Training. 
Figure 4: Level of corruption in Nigeria, 2010-2018

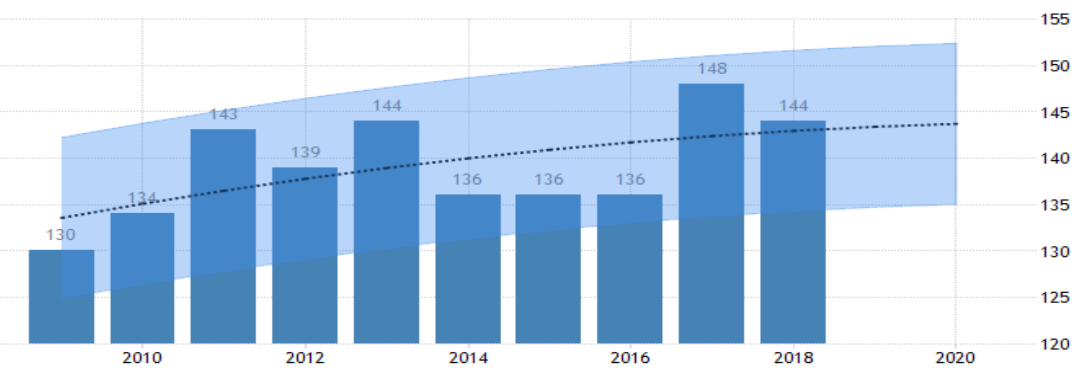

Source: Transparency International, 20I8. tradingeconomics.com

From the foregoing, it is evident that years of democratic practice in Nigeria's Fourth Republic have not really translated into much prospect of good governance. Concrete dividends of democracy appear not to have been sustainably realized. It should be pointed out that the whole essence of democracy is to determine and implement the will of the citizens in governance. The government is contracted through election to carry out the functions of authoritative allocation of resources at the instance of the people. Fulfilling this mandate requires the government to not only harness but generate resources to bringing about the greatest happiness for the greatest number of the citizenry. Where this is not feasible, democracy can be said to be non-existent, or at best, deficient.

\section{Democratic deficits in Nigeria's Fourth Republic: sundry implications}

Democracy is a system of popular control over governmental policies and decisions. For this to happen, a government needs to be responsive and accountable to popular control (Dahl I989). However, there are instances where democratic institutions are falling short of fulfilling the principles of responsiveness and accountability in their practice or operations. This lack of responsiveness to the popular preferences and democratic oversight is known as 'the democratic deficit' (Dahl I989). Democratic deficit is a great big gap where public engagement with political processes should be. To reiterate, a democratic deficit occurs when ostensibly democratic organizations or institutions (particularly governments) fall short of fulfilling the principles of democracy in their practices or operations (Rohrschneider 2002). 
The return to democratic governance on May 29, I999 to most Nigerians provided the opportunity to overturn the widespread developmental and political problems associated with prolonged military rule and at the same time a hope of great expectations of improved quality of wellbeing and governance. However, many years after the return to democratic rule, the huge expectations of many Nigerians have been largely undermined by poor governance, with its attendant socio-economic and political challenges. For instance, the Nigerian economy is currently characterized by the problems of poverty, widening income inequality between the rich and the poor, disinvestment, inflation, deindustrialization, mass unemployment and debt crisis. The Transparency International in its annual rating made Nigeria third, fourth and fifth most corrupt nation in the world in 2003,2004 and 2005 respectively. Thus corruption has eaten deep into the fabric of the nation and has shaken it to its foundation and tends to turn the efforts at democratic consolidation into a mere mirage. There has always been the use of violence or the threat of violence in the context of party politics (Jega 20I4). The ultimate prize is the capture and retention of political power at all costs.

More worrisome is the trajectory of party politics which has been associated with syndromes such as the phenomenon of godfatherism. Godfatherism is one of the biggest dangers to democracy today and paradoxically it only survives with government support (Gambo 2006). It has come to assume a dangerous dimension as a consequence of the systematic entrenchment of money politics in the country. It produces an unresponsive leadership and tends to negate all tenets of democratic process by obstructing candidate selection and even executive selection once government is installed. The activities of godfather tend to reduce the legitimacy of government and void the electoral value of the citizens (Edet 20I6; Odigbo 20I5). In addition, the inordinate culture of profligacy arising from the low level of accountability characterizing governmental processes, leading to abysmal economic performances and culminating in serious developmental misfortunes. The country's road, rail, electricity, water infrastructure, health and education institutions have been in a state of decay and total collapse.

Other signifiers of democratic deficits in Nigeria's Fourth Republic include over politicization of governance and insecurity, securitization and militarization of electioneering, electoral malfeasance, political impunity that smacks of disregard for the constitution and the rule of law, violation of human rights, emasculation of the civil society and the judiciary, to mention but a few. These indicators point to a bleak future for the country especially as it relates to democratic survival and consolidation. 


\section{Closing the gaps: mitigating democratic deficits in Nigeria}

Contemporary scholarly contestations about democracy and election are perceptibly not more on establishing the superiority of democracy on other forms of government or election as a means to achieving representative democratic leadership but on how best a society would vis-à-vis its peculiarities utilize the merits of election to achieve democratic value. To this end, mitigating democratic deficit in any polity fundamentally requires an all-inclusive approach bourgeoning from individual character re-orientation to institutional re-structuring based on the earnest determination to have a functional democracy where the greatest good of the greatest number is sacrosanct.

Going forward, elections should be free and fair in order that the public is enabled to select in or out the candidates of their choice into the country's leadership. People should determine who occupies what position and who does not through the power of the ballot so that through same, they can hold nonperforming leaders accountable. This is because the essence of democracy is the joint participation of the members of society in selecting, usually through free, fair and competitive elections, those whom they wish to have as their representatives in government. In this regard, political accountability and popular participation are promoted to the extent that the public feel a sense of an inclusive polity where their views and opinions are respected and their interests protected.

Furthermore, there should be adherence to democratic principles of rule of law and checks and balances. A state is democratic if there is devolution of governmental powers such that no single individual or institution has the opportunity to abuse power. It is therefore recommended here that rule of law alongside the supremacy of the constitution be upheld at all times in order to avoid abuse of power and all forms of impunity.

Additionally, empowerment of anticorruption agencies such as Independent Corrupt Practices Commission (ICPC) and the Economic and Financial Crimes Commission (EFCC) is also recommended. This will curb corrupt anti-democratic practices in the country. Similarly, a public reorientation on the ills of corruption is necessary so as to breed from the Nigerian homes, a people grounded in patriotism. By the same token, the leadership and followership arms of the polity should be given some civic orientation designed to inculcate a progressive political culture capable of breeding up a viable and consolidated democratic entity. 


\section{Conclusion}

Election remains the cornerstone of democracy due to its strategic importance as a framework for democratic transition as well as a critical indicator of democratic representation and consolidation. However, it appears that Nigeria has been witnessing voting without 'choosing', because the process of electing our political leaders is horrendously flawed. The manifestations of democratic deficits are evident in poor governance, blurred leadership resulting to incongruencies and policy summersault. Political and economic instability, flawed electoral process, rampant disregard to the rule of law and disobedience to court rulings as well as mortgaged judicial system amongst other colossal failures of democratic ideals seem to have made electoral democracy a mere caricature in the Nigeria's Fourth Republic. Democratic deficits are the consequence of structural inefficiencies inherent in the democratic framework due to poor design and the malfunctioning of the institutions resulting to a crisis of democracy.

The scorching persistent poverty, unemployment, poor economic management, widespread corruption, infrastructural deficits, low investor's confidence, debt overhang, inefficient public institutions, and lack of social trust and confidence in government are some of the indicators of democratic deficits in Nigeria's Fourth Republic. In fact, this has led to widespread collapse of social values and infrastructure, as well as the prevalence of illiteracy, insecurity of lives and properties, political corruption, authoritarianism, electoral malpractice, political violence and general governance failures. In order to entrench, sustain and consolidate democracy, there is a need for a strategic reformation of the key institutional frameworks of democracy. In other words, INEC, the legislature, the judiciary, the police, the constitution and the civil society should be reconfigured in line with the global democratic best practices to ensure credible elections as well as effective democratic representation and consolidation.

\section{References}

AAdeniyi, S. 20I8. "Democracy deficit and the deepening crisis of corruption in post-authoritarian Nigeria navigating the nexus." Taiwan Journal of Democracy, I4 (2)

Ademola, A. \& Adenuga, I. 20I5. "Elite theory and elite consolidation in Nigerian politics." International journal of banking, finance, management \& development studies. 3 (I). 
Adejumobi, S. 20II. "Election in Africa, A fading shadow of democracy." International Journal of Social Sciences, 3 (3), 5-I8.

Alemika, E. 2007. "Quality of elections, satisfaction within democracy and political trust in African". Afrobarometer working paper No. 84 .

Akinsanya, A. 2006. Oil and the Niger Delta crisis. The Guardian, Thursday, September 9th P.I6.

Appadorai, A. 2004. The substance of politics. Delhi: Oxford University Press.

Asiwaju, A. I. 2000. "Sharing best practice experiences in democracy building in non-French speaking African States." A Draft Paper Presented

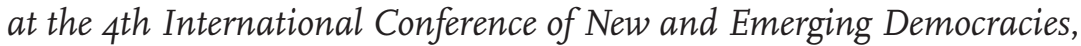
Cotonou, $4-6$ de dez.

Awojobi, O. 20I4. "Political corruption \& underdevelopment in Nigeria's $4^{\text {th }}$ Republic." International Journal of Innovation and Scientific Research. II (I).

Ayoade, J. 2006. "Godfather politics in Nigeria" IN: IFES, money, politics and corruption in Nigeria, IFES.

Bardhan, P. 2002. "Decentralization of Governance and Development." Journal of Economic Perspectives, I6(4), I85-205. http://dx.doi. org/10.I257/089533002320951037

Bardhan, P., \& Mookherjee, D. 2006a. The Rise of Local Governments: An Overview. In

. 2006b. Decentralization and Local Governance in Developing Countries: A Comparative Perspective. The MIT Press

. 2000. "Capture and Governance at Local and National Levels." The American Economic Review, 90 (2): 135-39.

Berouk M. 2008. "Democracy, elections \& political parties a conceptual overview with special emphasis on Africa." ISS Paper I66.

Bolaji, K. 20I4. “Toward Institutionalizing Credible Elections in Nigeria: A Review of Reform Measures by the Independent National Electoral Commission." In: Cordenillo, Raul (ed). Improving Electoral Practices: Case Studies and Practical Approaches. Stockholm: International IDEA.

Burton, J. 2019. Most Dangerous Countries in the World. Retrieved from https://www.worldatlas.com/articles/most-dangerous-countries-inthe-world.html

Carothers, T. 2007. "How democracies emerge: The sequencing fallacy." Journal of Democracy, I8 (I). 
Dahl, R. 1989. Democracy and its Critics. New Haven: Yale University Press. David, N. Manu, Y. \& Musa, A. 20I4. "Elections, electoral process and the challenges of democratization in Nigeria's Fourth Republic." Research on Humanities and Social Sciences. 4 (I7)

David, S. 20I5. Classical elites theory and libertarianism. Disponível em: https://www.lebertarianism.org/columns/classical-elite-theory-libertarianism.

Dasgupta, A. e V. Beard. 2007. "Community Driven Development, Collective Action and Elite Capture in Indonesia." Development and Change, 38 (2): 229-49.

Diamond, L. I999. Developing democracy: Toward consolidation. Baltimore: The Johns.

Dudley B. I982. Instability and Crisis in Nigeria-Politics and Crisis in Nigeria. Ibadan: Ibadan University Press.

D’Exelle, B. e A. Ridle. 2008. "Elite Capture, Political Voice and Exclusion from Aid: An Experimental Study." IZA Discussion Paper, No. 3673.

Edet, L. I. 20I6. Election Administration and Democratization Process in Nigeria: An Appraisal of 2007-2015, ACTA Universitatis Danubius, Vol. 8, no. 2

Egbegbulem, J. 20II. "Credible Elections and Democratic Consolidation in Nigeria: The Moral Imperative." Journal of Emerging Trends in Educational Research and Policy Studies, 2 (4) 246-250.

Fadakinte, M. 2013. "The nature and character of the Nigerian state: Explaining election crisis in a peripheral state." British Journal of Arts and Social Sciences, I2(II): 275-287.

Fawole, W. 2005. Voting without choosing: Interrogating the crisis of electoral democracy in Nigeria. In Lumumba-Kasongo, T. (ed.), Liberal democracy and its critics in Africa: Political dysfunction and the struggle for social progress. Londres : Zed Books.

Fairlie, J. I940. "The nature of political representation." The American political science review. 34 (2).

Frempong, A. 2006. Innovations in electoral politics in Ghana's Fourth Republic: An analysis. Democratic innovations in the South. Berlim: Friedrich Ebert Foundation.

Gambo, A. 2006. Godfatherism and electoral politics in Nigeria" in IFES, money, politics and corruption in Nigeria. IFES. 
Higley, J. e M. Burton 2006. Elite Foundations of Liberal Democracy. Lanham: Rowman and Littlefield.

Ibeanu, O. 2007. "Elections and the future of democracy in Nigeria. In. Jega, A. Q Ibeanu, O.(eds), Elections and the future of democracy in Nigeria. NPSA Conference Proceedings.

Igbokwe-Ibeto, C., Osakede, K., Nkomah, B., Kinge, R. 20I6. "Election and democratic consolidation in Nigeria: an analysis of the 2015 general elections." Arabian Journal of Business and Management Review (OMAN Chapter) 5 (Iо).

Igbuzor. O. 2005. "Constitutions, Electoral Process and the Future of Democratic Governance in Africa." A paper presented at the African Conference on Elections, Democracy and Governance organized by the Independent Electoral Commission of South Africa (IEC), the African Union (AU) and the African Association of Electoral Administrators (AAEA). Pretoria, África do Sul, 7-1o abr.

Jega, A. M. 20I4. Values, "Electoral Systems and the Importance of Successful elections in Nigeria's Foreign Policy" being a lecture delivered at the Nigerian Institute of International Affair (NIIA), Lagos, 23 de out.

. 2007. Democracy, good governance and development in Nigeria. Ibadan: Spectrum

Lasswel, H.D. 1936. Politics, who gets what, when and how. Nova York: Whitlesey House.

Linz, J. \& Stepan, A. I996. “Towards consolidated democracies.” Journal of Democracy, I (4), 34-56

Manufacturers Association of Nigeria (MAN) - Retrieved from http://www. manufacturersnigeria.org/membership.htm

Masaki, K. 2007. Power, Participation and Policy. The Emancipatory Evolution of the Elite-controlled Policy Process. Plymouth: Lexington Books.

Mottiar, S. 2002. Democratic consolidation in South Africa, http:/www.mottiar-Democratic consolidation- southafrica.pdf

National Bureau of Statistics (NBS). 20I8. Unemployment and Underemployment Report (Q4, 2017-Q3, 2018)

Nnadozie, O. 2005. "History of elections in Nigeria". In Onuh, G. \& Momoh, A. (eds), Elections and democratic consolidation in Nigeria. proceedings of 23rd Annual conference of Nigerian Political Science Association. Lagos: A-Triad Associates. 
Nwanegbo, C. J. 20I5. Electoral process and micro level rigging in 2015 general elections in Anambra West and Awka North Local Government Areas of Anambra State. Paper submitted for the two - day National conference on - The 2015 general elections in Nigeria: The real issues scheduled for June I7 - I8, 20I5 by The Electoral Institute (TEI), of the Independent National Electoral Commission (INEC).

Norris, P. 2orı. Democratic Deficit. Critical Citizens Revisited. Oxford: Oxford University Press.

Ogbonna, E. 20I2. "Democratic deficit and political economy of critical citizenry: Nigeria in perspective." Journal of Humanities and Social Science (IOSRJHSS) 1 (3).

Omotola, J.S. 20I4. "Elections and democratic transitions in Nigeria under the Fourth Republic." African Affairs, Iog (4), 535-553

Osabiya, B. 20I4. "Nigeria and democratic elections." Journal of Good Governance and Sustainable Development in Africa (JGGSDA). 2 (3).

Osaghae, C., \& Larry, D. I995. "Nigeria: The Uncivic Society and the Descent into Praetorianism”, In Larry, D., Linz, J. \& Lipset, S. (ed) Politics in Developing Countries: Comparing Experiences with Democracy. Boulder Colo.: Lynne Rienner.

Peter, L., Alemika, E., \& Michael, B., 2002. Down to Earth: Changes in attitudes toward democracy and markets in Nigeria. Michigan State University.

Platteau,J.P.2004. Monitoring Elite Capturein Community-Driven Development. Development and Change, 35(2),223-246.http://dx.doi.org/Io.IIII/ j.I467-7660.2004.00350.x

Przeworski, A. 1997. Democracy and the market: Political and economic reforms in Eastern Europe and Latin America. Cambridge: Cambridge University Press.

Rohrschneider, R. 2002. "The Democracy Deficit and Mass Support for an EU-wide Government", American Political Science Review, Vol. 46, No. 2: 463-475

Roller, E. 2005. The Performance of Democracies. Political Institutions and Public Policy. Oxford: Oxford University Press.

Russell, D.(2004. Democratic Challenges, Democratic Choices: The Erosion of Political Support in Advanced Industrial Democracies. Nova York: Oxford University Press.

Sahara Reporters. 20I9. Retrieved from saharareporters.com/20I9/06/05/918-million- Nigerians-are-extremely-poor-says-world-poverty-clock 
Sha, D. 2005. "Too much politics, too little democracy: Understanding the correlation between the elections and the democratic Transition" In Onuh, G. \& Momoh,A. (eds) Elections and democratic consolidation in Nigeria: Proceedings of 23rd annual conference of Nigerian Political Science Association. Lagos: A-Triad Associates

Schumpeter, J. A. I942. Capitalism, Socialism and Democracy. Nova York: Harper Brothers.

Transparency International 20I8. Level of corruption in Nigeria. wenr.wes. org.google.com

World Poverty Clock. 20I8. Retrieved from https://qz-com.cdn.ampproject. org

Yagboyaju, D. A. 2007. "Nigeria and the challenge of democratic consolidation: The Fourth Republic experience." African Journal of International Affairs and Development, I2 (2) 34 -54.

. 2008. "Nigeria and the Challenge of Democratic Consolidation: The Fourth Republic Experience." African Journal of International Affairs and Development. I2.I\&2: 44.

Zakaria, F. I997. "The rise of illiberal democracy." Foreign affairs; 76:6 


\section{ABSTRACT}

This paper is a commentary interrogating the phenomenon of democratic deficits in Nigeria's Fourth Republic based on an exploratory analysis of secondary sources. The essence of government is the fulfillment of public good. Democratic government is acclaimed to be most suited to determine and implement such a mandate. Incidentally, this has not been a general experience across the world's democracies. Successive democratic administrations in Nigeria's Fourth Republic have left a lot to be desired in relation to fulfilling their democratic mandate through proper representation and good governance. Series of elections have produced different crops of supposed people's representatives. Yet the existential conditions of the people have not been touched in a manner that justifies that these representatives rule at the instance of the people, let alone represent their interests and aspirations. The gaping deficits of democracy in that regard has warranted the submission of this paper to the effect that electoral democracy in Nigeria's Fourth Republic has not brought about the needed democratic dividends in terms of efficient governance and effective representation.

\section{KEYWORDS}

Democracy; Democratic deficits; Democratic representation; Election; Fourth Republic (Nigeria).

Received on February 2, 2020 Accepted on April 4, 2020 